\section{Contributors}

Matthew Burkes is a GP registrar in Chichester, West Sussex where he enjoyed a busy Paediatric rotation. Interested in postgraduate medical education, he has written or commissioned a series of articles designed to assist the GP trainee as they work through various specialty rotations. He would welcome any comments from the readership of the BJGP.

mattburkes@doctors.org.uk

Edoardo Cervoni

edoardo.cervoni@centrallancashire. nhs.uk

Mike Fitzpatrick

fitz@easynet.co.uk

Clare Gerada is Chair of RCGP Council and First5 task group lead. first5@rcgp.org.uk

Alexander Goodman undertook a 4-month rotation in Paediatircs during his Foundation Year 2 at Western Sussex Hospitals NHS Trust earlie this year. He is now a Specialist Trainee in Obstetrics and

Gynaecology at the Wessex Deanery.

Nyla Khan

nyla.a.khan@googlemail.com

Helen Lester

Helen.Lester@manchester.ac.uk

James Parsons originated the name First5 and the Five Pillars.

first5@rcgp.org.uk

\section{Jagdeep Sandu}

m0500168@sgul.ac.uk

Nigel Sparrow is the Chair of the Professional Development Board at the RCGP overseeing the First5 CPD project.

first5@rcgp.org.uk

Clare Taylor chaired the AiT

Committee 2008-9 and wrote the First5 paper, which was endorsed by RCGP Council November 2009. She is currently First5 CPD Fellow at RCGP. clarejtaylor@doctors.org.uk

\section{Gervase Vernon}

gervase@jth.demon.co.uk

Graham Watt is Professor of General Practice, University of Glasgow. g.watt@clinmed.gla.ac.uk

\title{
Getting the little things right
}

We've meant to take the kids to Anne Frank's house for years. Somehow, when there were three of them at home, and therefore three lots of out of school activities to schedule in a weekend, it just seemed too complicated. But with just the little one left at home, why not? (Although I am now officially a bad mother since missing the last lesson of the week - PE - to catch the plane is some sort of educational crime and I'm now on a list).

I had thought it would be the action of pushing past the book case, maybe seeing just how small the annexe was, hearing their friends' testimony of the last days in Auschwitz that would be the hardest or at least the most moving aspects. But no, it was the littlest thing the pencil lines on the door frame something most families have somewhere in their house, marks recording the heights of children who were never going to grow up, that made me stop and think.

The Anne Frank Museum also contains a rather wonderful exhibition with interactive short films of complex examples from around the world of how human rights can conflict with each other - which you can then vote on in real time. The UK-based example was whether the English Defence League should have been allowed to demonstrate in the middle of (wonderfully ethnically diverse) Birmingham city centre 16 months ago. Each of the films was an issue that hit the headlines but it made me think about all the little things that happen in everyday life that never make the news but where fear and stigma, misunderstanding, and negative stereotypes lurk and grow and can become, over time and with the 'right' nurturing, something unspeakable.

On Friday morning, before we got on the plane to Amsterdam, I interviewed two people, about my age, who'd been diagnosed with schizophrenia over 20 years ago. Neither had worked since, one was divorced and living in a hostel, one lived with his parents. Both spontaneously told me how bleak their lives were, with no prospect, as they saw it, of work or of finding love. Both sat at the edge of life, spent most of their days in a small room and ventured out rarely. In the space between interviews, I read through a transcript from last month where one young woman with schizophrenia told me that her previous GP had said she 'didn't look like someone with schizophrenia'. I've told this tale before but it bears retelling in this context. Not so long ago I ran a focus group with service users with schizophrenia and local GPs. As I sat with a group of three of four service users having our sandwiches before the session began, a GP walked into the room, looked at me and said 'oh - I see I'm the first person here.'

Before anyone thinks I've completely lost the plot, I'm not trying to draw direct parallels between how some of us behave with some of our patients and the evils of the Third Reich, but there are lessons here around getting the little things right in all we do. And that's why I worry a little about the current conversations that are going on nationally about commissioning. Companies are running around shouting loudly about the need for large scale leadership training programmes, for commissioning pathways in every clinical area and to do this all on a grand scale and at breakneck speed. But let's not forget the underpinning principles here for commissioning, not the big headline grabbing issues in the papers but the fundamental little things. The moment we think that someone is different from us, is somehow less deserving of our attention, and doesn't care as much about things as we do, then we fail as doctors and as commissioners. Commissioning is our opportunity to improve the health and the social care of those living at the edge, the seldom heard in society. Let's get our principles, the little things, right.

DOI: 10.3399/bjgp11X549162 